\title{
EFFECTS OF EIGHT-HOUR INTRAVENOUS INFUSIONS OF ACTH AND THE ADRENOCORTICAL STEROIDS IN NORMAL MAN. I. BASAL GASTRIC SECRETION, AND PLASMA AND URINARY PEPSINOGEN 1, 2
}

\author{
By B. I. HIRSCHOWITZ, D. H. P. STREETEN, ${ }^{3}$ J. A. LONDON, AND \\ H. M. POLLARD
}

(From the Department of Internal Medicine, University of Michigan Medical School, Ann
Arbor, Mich.)

(Submitted for publication November 12, 1956; accepted March 28, 1957)

While there appears to be general agreement that adrenocortical deficiency results in a reduction of gastric secretory activity both in man $(1-6)$ and in animals (7-11), no such unanimity of opinion exists regarding the effects of increased activity of the adrenal cortex on gastric secretion. Whereas some studies have shown that the administration of ACTH or of adrenocortical steroids may increase gastric acid and pepsin secretion (1214 ), others have failed to show any significant increase in acid or pepsin output by the stomach during the administration of ACTH (15-17) or cortisone or hydrocortisone $(18,19)$. Part of the confusion regarding any stimulant effect of increased adrenocortical activity stems from the use of urinary pepsinogen (uropepsin) levels as an index of gastric secretion.

In this study the effects of 8-hour infusions of ACTH, hydrocortisone, corticosterone, prednisolone, and aldosterone in normal males on the volume, acid, pepsin, and viscosity of gastric juice were studied, together with simultaneous measurements of blood and urinary pepsinogen. These results were compared with the effects of infusion of the vehicle alone and contrasted to the effects of a 4hour infusion of histamine. The results indicate that in general the hormones did not produce stimulation of gastric secretion compared with a known stimulant such as histamine.

An analysis of changes in urinary pepsinogen excretion indicates that the glucocorticoids in-

\footnotetext{
1 Presented before the National Meeting of the American Federation for Clinical Research at Atlantic City, May 1, 1955.

2 Supported in part by a grant from the United States Public Health Service (RG 4298) (c) and in part by a grant from the Horace H. Rackham School of Graduate Studies.

8 Investigator for the Howard Hughes Medical Institute.
}

crease the excretion of this substance. Furthermore, urinary pepsinogen has been found to be a poor index of gastric secretory activity for reasons which are discussed below.

\section{METHODS}

Sixteen normal adult male students were studied in the fasting state. In 15 of these subjects, each experiment was started between 7 and 8 A.M.; in the other, the experiments started at 11 A.M. To serve as a control period, the vehicle alone (1 per cent ethyl alcohol, 2.5 per cent dextrose, and 0.45 per cent $\mathrm{NaCl}$ in water) was infused for 3 hours, followed for 8 hours by the infusion of 25 international units of corticotropin (ACTH), $100 \mathrm{mg}$. hydrocortisone (F), $100 \mathrm{mg}$. corticosterone (B), $25 \mathrm{mg}$. prednisolone $(\Delta-\mathrm{F})$, or $400 \mu \mathrm{g}$. aldosterone in $1,000 \mathrm{ml}$. of the vehicle, followed in turn by a further 2 hours of infusion of vehicle. Thirteen subjects received ACTH; 11, hydrocortisone; 9, corticosterone; and 13, the vehicle alone. Eight subjects each had all four experiments, 2 of these also receiving prednisolone, and one of the latter an infusion of aldosterone as well. In further experiments on 6 of these subjects and 4 others, $1.2 \mathrm{mg}$. histamine base (as the diphosphate) in $500 \mathrm{ml}$. 0.9 per cent saline was infused over 4 hours after a one-hour control period.

Gastric tubes were passed either orally or nasally according to the subject's preference, and the gastric end positioned under fluoroscopic control in the proximal part of the pyloric antrum at the start of the experiment. At the end of each experiment the tube was again checked for position, and in no instance had it shifted significantly. Continuous aspiration of the stomach was maintained through the experiment and supplemented at half-hour intervals by hand suction with a syringe.

The consecutive half-hour samples of gastric juice were analyzed for free $\mathrm{H}^{+}$ion by electrometric titration to $\mathrm{pH} 3.3$ against $0.1 \mathrm{~N} \mathrm{NaOH}$; the samples were then refrigerated and at the end of each experiment they were centrifuged for 15 minutes at $2,500 \mathrm{rpm}$ and the viscosity of the supernate measured immediately at room temperature by measuring the time taken for a column of gastric juice to fall between two fixed points in a straight capillary tube (using $0.2 \mathrm{ml}$. fluid) (15). To determine the approximate changes in mucin concentration 
which might be responsible for the observed variations in viscosity of gastric juice by this method, the viscosity of a series of dilutions of hog mucin (Wilson 1701-W) in $0.04 \mathrm{~N} \mathrm{HCl}$ was measured (Figure 1). In order to establish the validity of measuring the viscosity of the gastric juice by this method, the results of 127 samples from some of these experiments were compared with values obtained with an Ostwald viscometer (using $3.5 \mathrm{ml}$. fluid) at $37^{\circ} \mathrm{C}$. in the same samples. The results, in terms of water as unity, were strictly comparable and a correlation coefficient gave an ' $r$ ' value of +0.88 . The standard error of 25 replicate measurements of one sample was \pm 0.14 per cent of the mean. The viscosity readings were not influenced by centrifugation at 2,500 rpm for periods ranging from 10 to 50 minutes after the initial centrifugation, suggesting that the substances imparting the extra viscosity were in solution. Bile contamination in the amounts observed had no appreciable effect on the viscosity of gastric juice. It should be added that the method employed here is not recommended for comparing different fluids, but appeared to be adequate for the serial determination of the viscosity of gastric juice.

Icteric index and pepsin concentration of the gastric juice were measured the next morning, the former by the method described for plasma (20), the latter using 2 per cent hemoglobin substrate and a 1:50 dilution of gastric juice (21). The total eosinophil count, employing a phloxine stain, and the plasma pepsinogen (21) content of blood samples collected every 2 hours were determined. Samples of urine collected overnight before each and after most experiments and every 2 hours during each experiment were assayed for pepsinogen by the hemoglobin method (22), modified only by extending the incubation time to 30 minutes. Urinary 17-hydroxycorticoids (23) were measured in the ACTH experiments only.

Contamination by saliva was reduced by having the subjects expectorate at frequent intervals. The icteric index of the gastric juice was used as some measure of the degree of duodenal regurgitation, in preference to continuous drainage of the duodenum by a second tube, which would require frequent fluoroscopic control and which of itself may stimulate gastric secretion (24). When the acid and pepsin concentrations, respectively, were plotted against the ieteric index it was found that normal duodenal regurgitation had no consistent effect on the concentration of either acid or pepsin. The icteric index was under 8.0 in 96 per cent of samples and under 3.0 in 80 per cent of samples in all the experiments. With this reassurance of the minimal role of duodenal regurgitation in neutralizing or diluting the gastric juice, all the samples were included in the calculations regardless of their bile contamination.

Calculations and statistical methods. In calculating the results, both the outputs and the mean concentrations of acid and pepsin for each hourly period were derived from the consecutive half-hour samples. The mean values include all the hourly samples in each 2 or 3-hour period in all the subjects. Thus, for 13 experiments 39 samples were used to calculate the mean and the standard deviation (S.D.) in the 3-hour control period and 26 samples in each successive 2-hour period. Because of the small numbers of figures in the prednisolone and aldosterone experiments these means have not been subjected to statistical testing.

To determine the variability in consecutive hourly collections of gastric juice volume, acid and pepsin output in the 13 vehicle (control) experiments, the coefficient of variation for each parameter in each subject was calculated. The mean ( \pm S.D.) of the coefficients of variation for volume was 34 per cent \pm 9 per cent; for pepsin output 35 per cent \pm 6 per cent; and for $\mathrm{HCl}$ output 67 per cent \pm 31 per cent. The greater variability in $\mathrm{HCl}$ output was due to the relatively large fluctuations in those subjects with the lowest output (under $1 \mathrm{mEq}$. per hr.) ; the higher the output, the steadier was the rate of secretion.

\section{RESULTS}

\section{Eosinophil and 17-hydroxycorticoid responses (Table I)}

All the subjects given ACTH had an adequate adrenocortical response as judged from the rise

TABLE I

Effect of intravenous infusions (a) on circulating eosinophils and (b) of ACTH on urinary excretion of 17-hydroxycorticoids

\begin{tabular}{|c|c|c|c|c|c|c|c|c|c|}
\hline \multirow{2}{*}{$\begin{array}{l}\text { Substance } \\
\text { infused }\end{array}$} & \multicolumn{2}{|c|}{ Control period } & \multicolumn{4}{|c|}{ During infusion } & \multicolumn{3}{|c|}{ After infusion } \\
\hline & $-3 \mathrm{hr}$. & $0 \mathrm{hr}$. & $0-2 \mathrm{hr}$. & $-4 \mathrm{hr}$. & $-6 \mathrm{hr}$. & $-8 \mathrm{hr}$. & $+2 \mathrm{hr}$. & $+3 \mathrm{hr}$. & $+12 \mathrm{hr}$. \\
\hline
\end{tabular}

(a) Mean total eosinophil count (cells/cu. mm. $\pm S . D$.

Vehicle

ACTH

Corticosterone

Hydrocortisone

Prednisolone

Aldosterone

ACTH

\begin{tabular}{|c|c|}
\hline $\begin{array}{c}193 \pm 100 \\
132 \pm 62 \\
167 \pm 49 \\
175 \pm 54 \\
260 \\
260\end{array}$ & $\begin{array}{c}152 \pm 76 \\
115 \pm 49 \\
149 \pm 50 \\
172 \pm 70 \\
225 \\
235\end{array}$ \\
\hline
\end{tabular}

(b) Mean urinary

$\begin{array}{cccc}150 \pm 69 & 140 \pm 64 & 171 \pm 82 & 155 \pm 82 \\ 99 \pm 31 & 55 \pm 30 & 23 \pm 21 & 12 \pm 7 \\ 147 \pm 53 & 143 \pm 79 & 116 \pm 74 & 123 \pm 78 \\ 142 \pm 78 & 50 \pm 45 & 21 \pm 33 & 12 \pm 13 \\ 230 & 151 & 97 & 47 \\ 227 & 286 & 297 & 269\end{array}$

$120 \pm 70$

$5 \pm 6$

$16 \pm 11$

168 
TABLE II

Effect of intravenous infusions on volume of gastric juice

\begin{tabular}{|c|c|c|c|c|c|c|c|}
\hline \multirow{3}{*}{$\begin{array}{c}\text { Substance } \\
\text { infused }\end{array}$} & \multirow{3}{*}{$\begin{array}{l}\text { No. of } \\
\text { studies }\end{array}$} & \multicolumn{6}{|c|}{ Mean volume of gastric juice $\left(m l_{.} / h r . \pm S . D.\right)$} \\
\hline & & \multirow{2}{*}{$\begin{array}{c}\begin{array}{c}\text { Control } \\
\text { period }\end{array} \\
3 \mathrm{hr} .\end{array}$} & \multicolumn{4}{|c|}{ During infusion } & \multirow{2}{*}{$\frac{\text { After infusion }}{+2 \mathrm{hr} .}$} \\
\hline & & & $0-2 \mathrm{hr}$. & $-4 \mathrm{hr}$. & $-6 \mathrm{hr}$. & $-8 \mathrm{hr}$. & \\
\hline $\begin{array}{l}\text { Vehicle } \\
\text { ACTH } \\
\text { Corticosterone } \\
\text { Hydrocortisone } \\
\text { Prednisolone }\end{array}$ & $\begin{array}{r}13 \\
13 \\
9 \\
11 \\
2\end{array}$ & $\begin{array}{l}63 \pm 36 \\
53 \pm 34 \\
44 \pm 21 \\
54 \pm 46 \\
60 \pm 29\end{array}$ & $\begin{array}{l}59 \pm 24 \\
51 \pm 41 \\
53 \pm 19 * \\
53 \pm 29 \\
47 \pm 10\end{array}$ & $\begin{array}{l}67 \pm 30 \\
53 \pm 33 \\
49 \pm 18 \\
57 \pm 42 \\
37 \pm 1\end{array}$ & $\begin{array}{l}54 \pm 27 \\
55 \pm 33 \\
54 \pm 21 * \\
53 \pm 29 \\
48 \pm 18\end{array}$ & $\begin{array}{l}65 \pm 24 \\
74 \pm 37^{*} \\
52 \pm 16^{*} \\
58 \pm 35 \\
78 \pm 4\end{array}$ & $\begin{array}{l}71 \pm 26 \\
78 \pm 38 \dagger \\
65 \pm 29 \dagger \\
63 \pm 40\end{array}$ \\
\hline Aldosterone & 1 & $63 \pm 8$ & $29 \pm 3$ & $30 \pm 3$ & $34 \pm 6$ & $56 \pm 4$ & $85 \pm 2$ \\
\hline Histamine I.V. & 10 & $\begin{array}{c}66 \pm 38 \\
(1 \mathrm{hr} .)\end{array}$ & $166 \pm 51 \dagger$ & $225 \pm 72 \dagger$ & $201 \pm 55 \dagger$ & $202 \pm 94 \dagger$ & \\
\hline
\end{tabular}

* $p<0.05$ Significance of increase over control period by Student's ' $t$ ' test. All other differences from control $\dagger \mathrm{p}<0.01\}$ periods are not significant.

in 17-hydroxycorticoids and the fall in circulating eosinophils. A similar eosinophil response was elicited by the administration of hydrocortisone and prednisolone. No significant eosinophil changes were noted with the vehicle infusions or following the administration of corticosterone or aldosterone.

\section{Volume of gastric juice}

Table II details the mean hourly volume of gastric juice aspirated in the 3-hour control period and in each succeeding 2-hour period of the experiments. The volumes were significantly increased over the control period in the last 2 hours of ACTH infusion and in the succeeding 2 hours, as well as during the entire period (except the second 2 hours) of the corticosterone infusion and in the 2 hours following its infusion. The magnitude of these increases, though statistically significant, did not approach 25 per cent of the increases noted with histamine. There were no significant increases in the volume of gastric secretion in either the vehicle or in the hydrocortisone or the prednisolone experiments.

\section{Output of hydrochloric acid (Table III)}

The output of acid did not change significantly from the corresponding control values during the infusion of any of the hormones. The only statistically significant rise in the output of acid occurred in the 2 hours after the end of the corticosterone infusion. Even in this period, however, the actual output of acid was of the same order of magnitude as in the corresponding period of the

TABLE III

Effect of intravenous infusions on gastric output of hydrochloric acid

\begin{tabular}{|c|c|c|c|c|c|c|c|}
\hline \multirow{3}{*}{$\begin{array}{c}\text { Substance } \\
\text { infused }\end{array}$} & \multirow{3}{*}{$\begin{array}{l}\text { No. of } \\
\text { studies }\end{array}$} & \multicolumn{6}{|c|}{ Mean gastric output of $\mathrm{HCl}(m E q . / h r . \pm S . D)}$. \\
\hline & & \multirow{2}{*}{$\begin{array}{c}\begin{array}{c}\text { Control } \\
\text { period }\end{array} \\
3 \mathrm{hr} .\end{array}$} & \multicolumn{4}{|c|}{ During infusion } & \multirow{2}{*}{$\begin{array}{c}\begin{array}{c}\text { After } \\
\text { infusion }\end{array} \\
+2 \mathrm{hr} .\end{array}$} \\
\hline & & & 0-2 hr. & $-4 \mathrm{hr}$. & $-6 \mathrm{hr}$. & $-8 \mathrm{hr}$. & \\
\hline $\begin{array}{l}\text { Vehicle } \\
\text { ACTH } \\
\text { Corticosterone } \\
\text { Hydrocortisone } \\
\text { Prednisolone }\end{array}$ & $\begin{array}{r}13 \\
13 \\
9 \\
11 \\
2\end{array}$ & $\begin{array}{l}2.38 \pm 2.6 \\
1.94 \pm 2.3 \\
1.67 \pm 1.59 \\
2.39 \pm 3.2 \\
1.35 \pm .67 \\
\quad(5 \text { hr. })\end{array}$ & $\begin{array}{l}1.39 \pm 1.3 \\
1.67 \pm 2.9 \\
1.60 \pm 1.1 \\
2.11 \pm 2.19 \\
1.05 \pm .33\end{array}$ & $\begin{array}{l}2.18 \pm 2.12 \\
1.55 \pm 1.97 \\
2.27 \pm 1.8 \\
2.56 \pm 3.3 \\
1.0 \pm .41\end{array}$ & $\begin{array}{l}1.74 \pm 1.78 \\
1.82 \pm 2.07 \\
2.04 \pm 1.3 \\
2.17 \pm 2.8 \\
1.72 \pm .97\end{array}$ & $\begin{array}{l}2.14 \pm 1.73 \\
2.52 \pm 2.52 \\
2.16 \pm 1.2 \\
2.35 \pm 2.6 \\
3.02 \pm .54^{*}\end{array}$ & $\begin{array}{l}2.56 \pm 1.29 \\
3.14 \pm 3.06 \\
2.87 \pm 1.8 \dagger \\
2.48 \pm 2.5\end{array}$ \\
\hline $\begin{array}{l}\text { Aldosterone } \\
\text { Histamine }\end{array}$ & 10 & $\begin{array}{c}1.42 \pm .59 \\
(4 \mathrm{hr} .) \\
1.0 \pm .62 \\
(1 \mathrm{hr} .)\end{array}$ & $\begin{array}{c}1.07 \pm .15 \\
(1 \mathrm{hr} .) \\
15.9 \pm 6.3 \dagger\end{array}$ & $\begin{array}{c}1.23 \pm .10 \\
(2 \mathrm{hr} .) \\
24.8 \pm 8.0 \dagger\end{array}$ & $\begin{array}{c}1.91 \pm .43 \\
(3 \mathrm{hr} .) \\
24.4 \pm 10.6 \dagger\end{array}$ & $\begin{array}{c}2.87 \pm .40 \\
(4 \mathrm{hr} .) \\
21.0 \pm 12.0 \dagger\end{array}$ & $3.53 \pm .45 \dagger$ \\
\hline
\end{tabular}

\footnotetext{
${ }_{\dagger}^{*} \mathrm{p}<0.051$ Significance of increase over control period by Student's ' $t$ ' test. Other differences not significant.
} 
TABLE IV

Effect of intravenous infusions on output of gastric pepsin

\begin{tabular}{|c|c|c|c|c|c|c|c|}
\hline \multirow{3}{*}{$\begin{array}{c}\text { Substance } \\
\text { infused }\end{array}$} & \multirow{3}{*}{$\begin{array}{l}\text { No. of } \\
\text { studies }\end{array}$} & \multicolumn{6}{|c|}{ Mean output of gastric pepsin (P.U. (lhousands) per hour \pm S.D.) } \\
\hline & & \multirow{2}{*}{\begin{tabular}{|c|}
$\begin{array}{c}\text { Control } \\
\text { period }\end{array}$ \\
$3 \mathrm{hr}$.
\end{tabular}} & \multicolumn{4}{|c|}{ During infusion } & \multirow{2}{*}{$\frac{\text { After infusion }}{+2 \mathrm{hr} .}$} \\
\hline & & & $0-2 \mathrm{hr}$. & $-4 \mathrm{hr}$. & $-6 \mathrm{hr}$. & $-8 \mathrm{hr}$. & \\
\hline $\begin{array}{l}\text { Vehicle } \\
\text { ACTH } \\
\text { Corticosterone } \\
\text { Hydrocortisone } \\
\text { Prednisolone }\end{array}$ & $\begin{array}{r}13 \\
13 \\
9 \\
11 \\
2\end{array}$ & $\begin{array}{c}77.7 \pm 53.9 \\
52.7 \pm 27.8 \\
62.4 \pm 24.1 \\
65.1 \pm 37.4 \\
65 \pm 38.9 \\
(5 \mathrm{hr} .)\end{array}$ & $\begin{array}{l}74.5 \pm 39 \\
51.9 \pm 29 \\
73.0 \pm 25.8 \\
70.6 \pm 35.6 \\
53.5 \pm 18.6\end{array}$ & $\begin{array}{l}95.8 \pm 59 \\
56.3 \pm 31.8 \\
80.4 \pm 26.3^{*} \\
69.4 \pm 41.3 \\
58.3 \pm 24.8\end{array}$ & $\begin{array}{l}88.5 \pm 42 \\
62.0 \pm 27.6 \\
87.8+35.1 \dagger \\
63.6 \pm 33.7 \\
75 \pm 41.4\end{array}$ & $\begin{array}{l}97.1 \pm 43 \\
66.6 \pm 32.4 \\
88.4 \pm 38 \dagger \\
61.9 \pm 45.6 \\
89.5 \pm 33.6\end{array}$ & $\begin{array}{c}108 \pm 36.6 \\
75.7 \pm 34.9 \dagger \\
102.1 \pm 41.6 \dagger \\
67.2 \pm 51\end{array}$ \\
\hline Aldosterone & 1 & $\begin{array}{c}59.5 \pm 21.6 \\
(4 \mathrm{hr} .)\end{array}$ & $67 \pm 1$ & $66 \pm 3$ & $77 \pm 14$ & $114 \pm 6.4$ & $111 \pm 11$ \\
\hline Histamine & 10 & $\begin{array}{c}61.8 \pm 31.5 \\
(1 \mathrm{hr} .)\end{array}$ & $\begin{array}{c}(1 \mathrm{hr} .) \\
214 \pm 76 \dagger\end{array}$ & $\begin{array}{c}(2 \mathrm{hr} .) \\
244 \pm 89 \dagger\end{array}$ & $\begin{array}{c}(3 \mathrm{hr} .) \\
218 \pm 78 \dagger\end{array}$ & $\begin{array}{c}(4 \mathrm{hr} .) \\
257 \pm 107 \dagger\end{array}$ & \\
\hline
\end{tabular}

${ }^{*} p<0.05$ Significance of increase over control period by Student's ' $t$ ' test. All other differences from mean control $t \mathrm{p}<0.01\}$ not statistically significant.

vehicle experiments. Furthermore, none of the mean values of acid output approached 20 per cent of the sustained levels during the histamine infusion.

\section{Output of pepsin (Table IV)}

There was a small, progressive increase in the output of pepsin in all of the experiments, except those in which hydrocortisone was infused. When compared with the values during the corresponding control periods, the pepsin output was significantly increased during the last 6 hours of the corticosterone infusion and after the end of the infusions of corticosterone and of ACTH. The actual output of pepsin in the hormone experiments, however, was always lower than in the corresponding periods in the vehicle experiments, and the absolute increases observed in the hormone experiments were never greater than 25 per cent of the increases which occurred with the histamine infusions.

\section{The composition of gastric juice}

The over-all secretory activity of the stomach as judged by the output of water, acid, and pepsin remained substantially unaltered under the in-

TABLE $V$

Effect of intravenous infusions on concentration of hydrogen ion and pepsin in gastric juice

\begin{tabular}{|c|c|c|c|c|c|c|}
\hline \multirow{2}{*}{$\begin{array}{c}\text { Substance } \\
\text { infused }\end{array}$} & \multirow{2}{*}{$\begin{array}{c}\begin{array}{c}\text { Control } \\
\text { period }\end{array} \\
3 \mathrm{hr} .\end{array}$} & \multicolumn{4}{|c|}{ During hormone infusion } & \multirow{2}{*}{$\frac{\begin{array}{c}\text { After } \\
\text { infusion }\end{array}}{+2 \mathrm{hr} .}$} \\
\hline & & 0-2 hr. & $-4 \mathrm{hr}$. & $-6 \mathrm{hr}$. & $-8 \mathrm{hr}$. & \\
\hline \multicolumn{7}{|c|}{ Mean $\mathrm{H}^{+}$concentration ( $m E q . /$ liter) } \\
\hline $\begin{array}{l}\text { Vehicle } \\
\text { ACTH } \\
\text { Corticosterone } \\
\text { Hydrocortisone } \\
\text { Prednisolone } \\
\text { Aldosterone } \\
\text { Histamine }\end{array}$ & $\begin{array}{l}38 \\
37 \\
38 \\
44 \\
22 \\
22\end{array}$ & $\begin{array}{c}24 \\
33 \\
30 \\
40 \\
22 \\
37 \\
(1 \mathrm{hr} .) \\
96\end{array}$ & $\begin{array}{c}32 \\
29 \\
46 \\
45 \\
27 \\
41 \\
(2 \mathrm{hr} .) \\
110\end{array}$ & $\begin{array}{c}32 \\
33 \\
38 \\
41 \\
36 \\
56 \\
(3 \mathrm{hr} .) \\
121\end{array}$ & $\begin{array}{c}33 \\
34 \\
41 \\
40 \\
39 \\
51 \\
(4 \mathrm{hr} .) \\
104\end{array}$ & $\begin{array}{l}36 \\
40 \\
44 \\
39 \\
41\end{array}$ \\
\hline \multicolumn{7}{|c|}{ Mean pepsin concentration $(P . U . / \mathrm{ml})}$. \\
\hline $\begin{array}{l}\text { Vehicle } \\
\text { ACTH } \\
\text { Corticosterone } \\
\text { Hydrocortisone } \\
\text { Prednisolone } \\
\text { Aldosterone }\end{array}$ & $\begin{array}{r}1,233 \\
1,013 \\
1,418 \\
1,206 \\
1,083 \\
944\end{array}$ & \multirow[t]{2}{*}{$\begin{array}{c}1,262 \\
1,018 \\
1,377 \\
1,332 \\
1,138 \\
2,310 \\
(1 \mathrm{hr} .) \\
1,289\end{array}$} & \multirow[t]{2}{*}{$\begin{array}{l}1,430 \\
1,062 \\
1,641 \\
1,217 \\
1,576 \\
2,200 \\
(2 \mathrm{hr} .) \\
1,084\end{array}$} & \multirow[t]{2}{*}{$\begin{array}{c}1,639 \\
1,127 \\
1,626 \\
1,200 \\
1,562 \\
2,265 \\
(3 \mathrm{hr} .) \\
1,085\end{array}$} & \multirow[t]{2}{*}{$\begin{array}{c}1,494 \\
900 \\
1,700 \\
1,067 \\
1,147 \\
2,036 \\
(4 \mathrm{hr} .) \\
1,272\end{array}$} & \multirow[t]{2}{*}{$\begin{array}{r}1,521 \\
970 \\
1,571 \\
1,067 \\
1,306\end{array}$} \\
\hline Histamine & 936 & & & & & \\
\hline
\end{tabular}


TABLE V

Effect of intravenous infusions on viscosity of gastric juice

\begin{tabular}{|c|c|c|c|c|c|c|c|}
\hline \multirow{3}{*}{$\begin{array}{l}\text { Subetance } \\
\text { infused }\end{array}$} & \multirow{3}{*}{$\begin{array}{l}\text { No. of } \\
\text { studies }\end{array}$} & \multicolumn{6}{|c|}{ Mean vircometer readings (seconds $\pm S . D$.$) (Water 7.35 \pm 0.05$ sec.) } \\
\hline & & \multirow{2}{*}{$\frac{\text { Control }}{3 \mathrm{hr} .}$} & \multicolumn{4}{|c|}{ During infusion } & \multirow{2}{*}{$\begin{array}{c}\begin{array}{c}\text { After } \\
\text { infusion }\end{array} \\
+2 \mathrm{hr} .\end{array}$} \\
\hline & & & 0-2 hr. & $-4 \mathrm{hr}$. & $-6 \mathrm{hr}$. & $-8 \mathrm{hr}$. & \\
\hline $\begin{array}{l}\text { Vehicle } \\
\text { ACTH } \\
\text { Corticosterone } \\
\text { Hydrocortisone } \\
\text { Prednisolone } \\
\text { Aldosterone }\end{array}$ & $\begin{array}{r}13 \\
12 \\
9 \\
11 \\
2 \\
1\end{array}$ & $\begin{array}{l}8.59 \pm 3.2 \\
8.97 \pm 2.2 \\
8.38 \pm .92 \\
8.67 \pm 1.31 \\
8.50 \\
8.46\end{array}$ & $\begin{array}{l}8.32 \pm 1.6 \\
8.14 \pm .75 \\
8.35 \pm 1.78 \\
8.72 \pm 2.6 \\
8.47 \\
8.82\end{array}$ & $\begin{array}{l}8.05 \pm 1.3 \\
8.15 \pm .69 \\
7.96 \pm .12 \\
8.04 \pm 1.0 \\
8.44 \\
7.92\end{array}$ & $\begin{array}{l}8.30 \pm 1.4 \\
7.95 \pm .64^{*} \\
7.94 \pm .54 \\
8.55 \pm 2.8 \\
8.09 \\
8.28\end{array}$ & $\begin{array}{l}8.44 \pm 1.6 \\
7.82 \pm .55 \dagger \\
7.88 \pm .27^{*} \\
8.13 \pm 1.2 \\
7.80 \\
\quad 7.92\end{array}$ & $\begin{array}{l}8.06 \pm 1.3 \\
7.71 \pm .55 \dagger \\
8.14 \pm .61 \\
8.08 \pm 1.2 \\
\quad 7.68\end{array}$ \\
\hline
\end{tabular}

$\left.\begin{array}{l}* p<0.05 \\ +p<0.01\end{array}\right\}$ Significance of decrease from control value by Student's ' $t$ ' test. Other differences not significant.

fluence of the 8-hour infusion of ACTH or adrenocortical steroids. However, there were some significant changes in composition of the gastric juice.

\section{Concentrations of acid and pepsin (Table V)}

There was essentially no difference between the concentrations of acid in any of the hormone experiments and in their own control periods or in

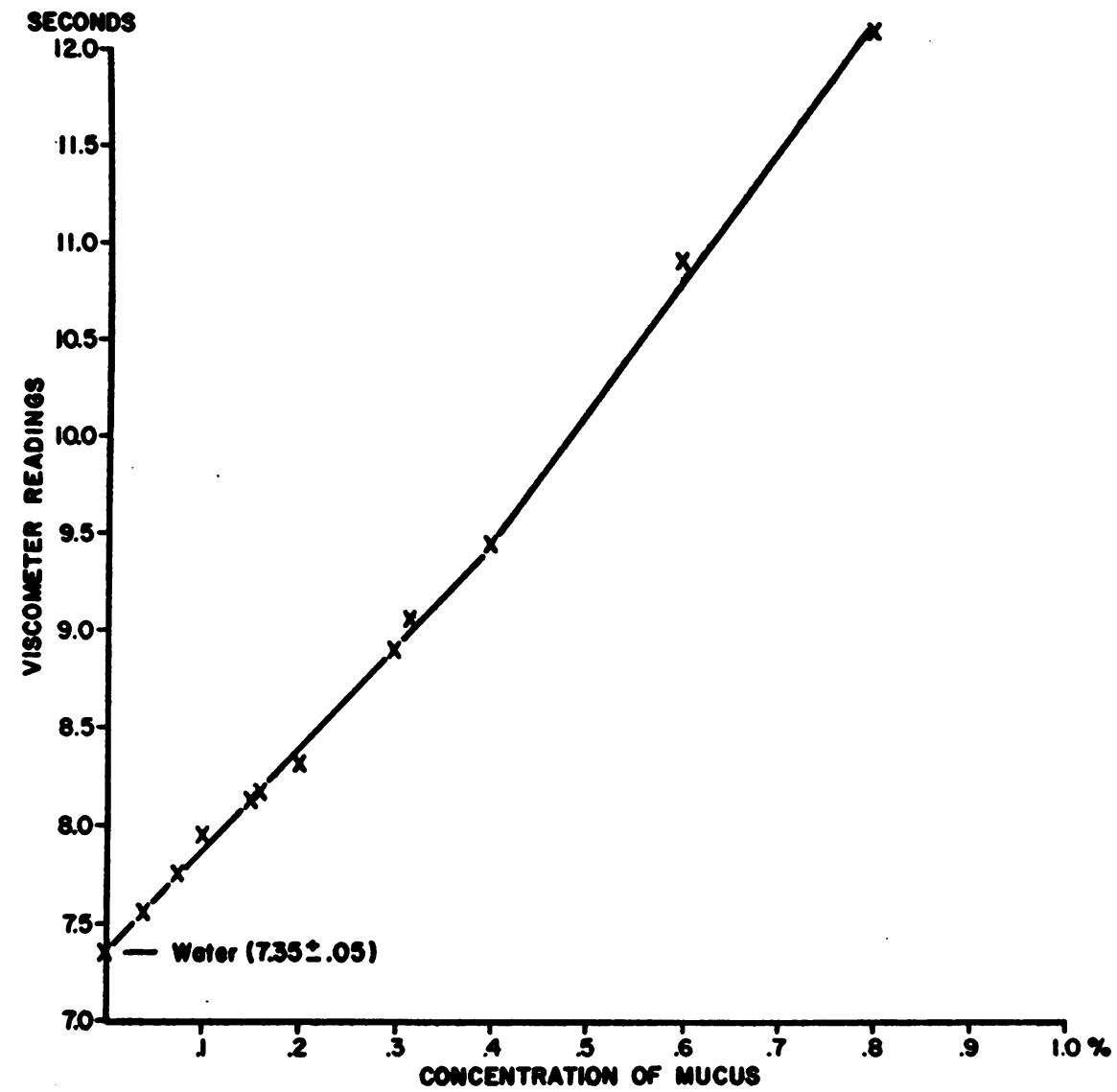

Fig. 1. Viscometer Readings of Increasing Concentrations of Wilson Hog Stomach Mucti (1701-W) in $0.04 \mathrm{~N}$ HCL, in the Range of Observed Gastric JUICE Viscosity 
TABLE VII

Effect of intravenous infusions on concentration of pepsinogen in plasma

\begin{tabular}{|c|c|c|c|c|c|c|c|c|}
\hline \multirow{3}{*}{$\begin{array}{l}\text { Substance } \\
\text { infused }\end{array}$} & \multirow{3}{*}{$\begin{array}{l}\text { No. of } \\
\text { studies }\end{array}$} & \multicolumn{7}{|c|}{ Mean pepsinogen concentration $(P . U$. per $100 \mathrm{ml} . \pm S . D)}$. \\
\hline & & \multicolumn{2}{|c|}{ Control period } & \multicolumn{4}{|c|}{ During infusion } & \multirow{2}{*}{$\begin{array}{c}\begin{array}{c}\text { After } \\
\text { infusion }\end{array} \\
+2 \mathrm{hr} .\end{array}$} \\
\hline & & $-3 \mathrm{hr}$. & $0 \mathrm{hr}$. & $2 \mathrm{hr}$. & $4 \mathrm{hr}$. & $6 \mathrm{hr}$. & $8 \mathrm{hr}$. & \\
\hline $\begin{array}{l}\text { Vehicle } \\
\text { ACTH } \\
\text { Corticosterone } \\
\text { Hydrocortisone } \\
\text { Prednisolone } \\
\text { Aldosterone }\end{array}$ & $\begin{array}{r}13 \\
13 \\
9 \\
11 \\
2 \\
1\end{array}$ & $\begin{array}{c}12.3 \pm 2.4 \\
12.1 \pm 4.9 \\
12.3 \pm 2.6 \\
12.1 \pm 3.3 \\
7.5 \\
7.9\end{array}$ & $\begin{array}{c}11.6 \pm 3.0 \\
12.8 \pm 5.0 \\
13.2 \pm 3.2 \\
14.5 \pm 2.8 \\
7.5 \\
8.1\end{array}$ & $\begin{array}{c}12.6 \pm 3.2 \\
14.2 \pm 6.2 \\
16.7 \pm 4.7 \\
11.2 \pm 3.8 \\
7.8 \\
8.7\end{array}$ & $\begin{array}{c}13.7 \pm 5.4 \\
12.8 \pm 4.8 \\
13.6 \pm 3.0 \\
12.2 \pm 2.4 \\
7.1 \\
9.3\end{array}$ & $\begin{array}{c}12.8 \pm 3.4 \\
11.7 \pm 5.0 \\
10.5 \pm 3.8 \\
12.4 \pm 3.4 \\
7.1 \\
8.7\end{array}$ & $\begin{array}{c}11.6 \pm 3.5 \\
10.6 \pm 5.1 \\
11.7 \pm 5.3 \\
13.5 \pm 5.2 \\
7.8 \\
8.9\end{array}$ & $\begin{array}{c}14.0 \pm 5.1 \\
11.0 \pm 5.8 \\
16.2 \pm 7.5 \\
12.7 \pm 2.3 \\
10.3\end{array}$ \\
\hline
\end{tabular}

the vehicle experiments. With infusion of the vehicle alone, the concentration of pepsin tended to rise as the experiment progressed. There was a persistent but smaller rise in the concentration of pepsin with the infusion of corticosterone, and no essential changes in concentration with the infusion of ACTH or of hydrocortisone or prednisolone. The most striking changes occurred with the infusion of aldosterone, during which the concentrations of pepsin and acid more than doubled. Such an increase in pepsin concentration was not observed in any other experiment.

\section{Viscosity of gastric juice}

The normal viscosity of gastric juice is little higher than water (Table VI) but relatively small changes in viscosity of the fluid represent, in terms of a standard solution of mucin, relatively large changes in concentrations of dissolved mucus (Figure 1).

The infusions of vehicle produced no significant changes in viscosity compared to the control period. Under the influence of $\mathrm{ACTH}$ there was a progressive fall in viscosity which became manifest in the first 2 hours of infusion, statistically significant by the sixth hour, and highly significant in the following 4 hours. There was a general tendency for the viscosity to fall in the other experiments, but only in the last 2 hours of the corticosterone infusion was this fall statistically significant.

In general, the decrease in viscosity, representing presumably dissolved mucus, was also observed in visible mucus. This was especially obvious with the ACTH infusions, during which visible mucus tended to disappear from the gastric juice.

\section{Plasma pepsinogen concentrations}

There was no significant variation in plasma pepsinogen concentration in any of the experiments (Table VII), and all the subjects had levels which were well within the normal range (25). This stability contrasted with the rather marked changes in excretion of pepsinogen in the urine, described below.

TABLE VIII

Effect of intravenous infusions on urinary excretion of pepsinogen

\begin{tabular}{|c|c|c|c|c|c|c|c|c|c|}
\hline \multirow{3}{*}{$\begin{array}{c}\text { Substance } \\
\text { infused }\end{array}$} & \multirow{3}{*}{$\begin{array}{l}\text { No. of } \\
\text { studies }\end{array}$} & \multicolumn{8}{|c|}{ Mean urinary pepsinogen $(P . U . / h r . \pm S . D)}$. \\
\hline & & \multirow{2}{*}{$\begin{array}{c}\text { Overnight } \\
\text { before }\end{array}$} & \multirow{2}{*}{$\begin{array}{l}\text { Control } \\
3 \mathrm{hr} .\end{array}$} & \multicolumn{5}{|c|}{ During infusion } & \multirow{2}{*}{$\begin{array}{c}\text { Overnight } \\
\text { after }\end{array}$} \\
\hline & & & & $0-2 \mathrm{hr}$. & $-4 \mathrm{hr}$. & $-6 \mathrm{hr}$. & $-8 \mathrm{hr}$. & $+2 \mathrm{hr}$. & \\
\hline $\begin{array}{l}\text { Vehicle } \\
\text { ACTH } \\
\text { Corticosterone } \\
\text { Hydrocortisone } \\
\text { Prednisolone* } \\
\text { Aldosterone* }\end{array}$ & $\begin{array}{r}12 \\
11 \\
9 \\
10 \\
1 \\
1\end{array}$ & $\begin{array}{c}89 \pm 64 \\
153 \pm 93 \\
91 \pm 56 \\
101 \pm 48 \\
153 \\
142\end{array}$ & $\begin{array}{c}103 \pm 48 \\
167 \pm 92 \\
137 \pm 83 \\
130 \pm 57 \\
142 \\
148\end{array}$ & $\begin{array}{l}115 \pm 42 \\
196 \pm 112 \\
123 \pm 58 \\
196 \pm 84 \dagger \\
142 \\
142\end{array}$ & $\begin{array}{l}115 \pm 42 \\
220 \pm 132 \\
118 \pm 71 \\
251 \pm 165 \ddagger \\
204 \\
99\end{array}$ & $\begin{array}{c}107 \pm 40 \\
243 \pm 120 \\
124 \pm 59 \\
379 \pm 429 \dagger \\
182 \\
98\end{array}$ & $\begin{array}{c}117 \pm 73 \\
243 \pm 83 \dagger \\
186 \pm 109 \\
248 \pm 119 \ddagger \\
198 \\
109\end{array}$ & $\begin{array}{c}123 \pm 74 \\
222 \pm 108 \\
145 \pm 87 \\
255 \pm 107 \ddagger \\
102\end{array}$ & $\begin{array}{c}148 \pm 54 \\
106 \pm 73 \\
171 \pm 79 \\
152\end{array}$ \\
\hline
\end{tabular}

* Same subject.

$\left.\begin{array}{l}\dagger p<0.05 \\ \ddagger \mathrm{p}<0.01\end{array}\right\}$ Significance of increase over control period. Other differences not significant. 


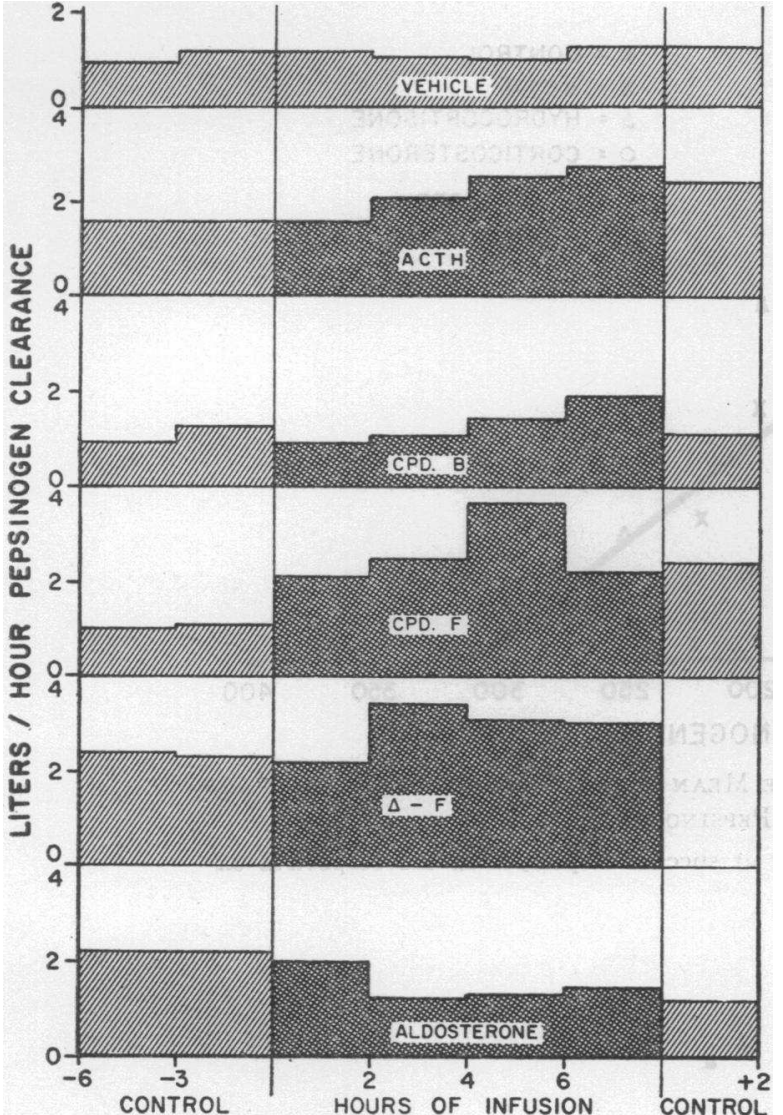

Fig. 2. Mean Effects of Various Infusions on the Renal Clearance of Pepsinogen

\section{Urinary pepsinogen excretion (Table VIII)}

The urinary pepsinogen excretion in the vehicle experiments remained fairly constant during the day, with a slightly lower overnight level. The coefficients of variation of the day samples in 12 vehicle experiments ranged from 1 per cent to 45 per cent with a mean of 22.8 per cent \pm 14 . There was less variation within individuals than between individuals, and it was felt that 2-hour sampling was accurate enough despite large variations in urine volume $(26$, Table I).

Under the influence of ACTH there was a rise in urinary pepsinogen output within 2 hours, reaching a plateau by the sixth hour. No subject failed to experience a moderate to large increase in pepsinogen excretion under the influence of ACTH. With hydrocortisone 2 of the 10 subjects had no increase in urinary pepsinogen excretion. However, the mean response to the infusions of hydrocortisone was a statistically significant increase over the control period, from the second hour of the hormone infusion until the 2 -hour period after the completion of the infusion. With corticosterone, 5 of the 9 subjects showed a small increase in pepsinogen excretion, but the mean showed no significant increase for the group over the control period. With aldosterone there was a drop in urinary pepsinogen excretion, and with prednisolone an increase in the one experiment where urinary pepsinogen was measured. The effects of hydrocortisone persisted during the night after the infusion, whereas the effects of the other hormones did not continue for more than 2 hours after their infusion.

\section{The clearance of pepsinogen}

The calculated renal clearances of pepsinogen indicate, as would be expected from the plasma and urinary pepsinogen figures, that hydrocortisone more than doubled the clearance, and that ACTH caused a moderate increase (Figure 2).

\section{The relation of urinary pepsinogen to glucocorti- coid activity}

Comparison of the output of urinary pepsinogen with that of 17-hydroxycorticoids in the ACTH experiments showed some association between the two $(\mathrm{r}=+0.43, \mathrm{n}=55, \mathrm{p}<0.01)$. Furthermore, the mean urinary pepsinogen excretion and mean total eosinophil counts showed an excellent negative linear correlation $(\mathrm{r}=-0.88, \mathrm{p}<$ 0.001 ), (Figure 3).

\section{Relation of urinary pepsinogen to gastric pepsin secretion}

In each experiment on each subject the output of pepsinogen in the urine was compared with the output of pepsin into the stomach, in three periods comprising, respectively, the entire control period preceding, the 8 hours during, and the 2 hours following the hormone infusion. These data (Figure 4) show no correlation between urinary pepsinogen excretion and the simultaneous secretion of pepsin into the stomach. The calculated ratios of Gastric pepsin: Urinary pepsinogen for these periods showed very wide fluctuations ranging from $88: 1$ to $2,650: 1$ with a mean ratio in the 


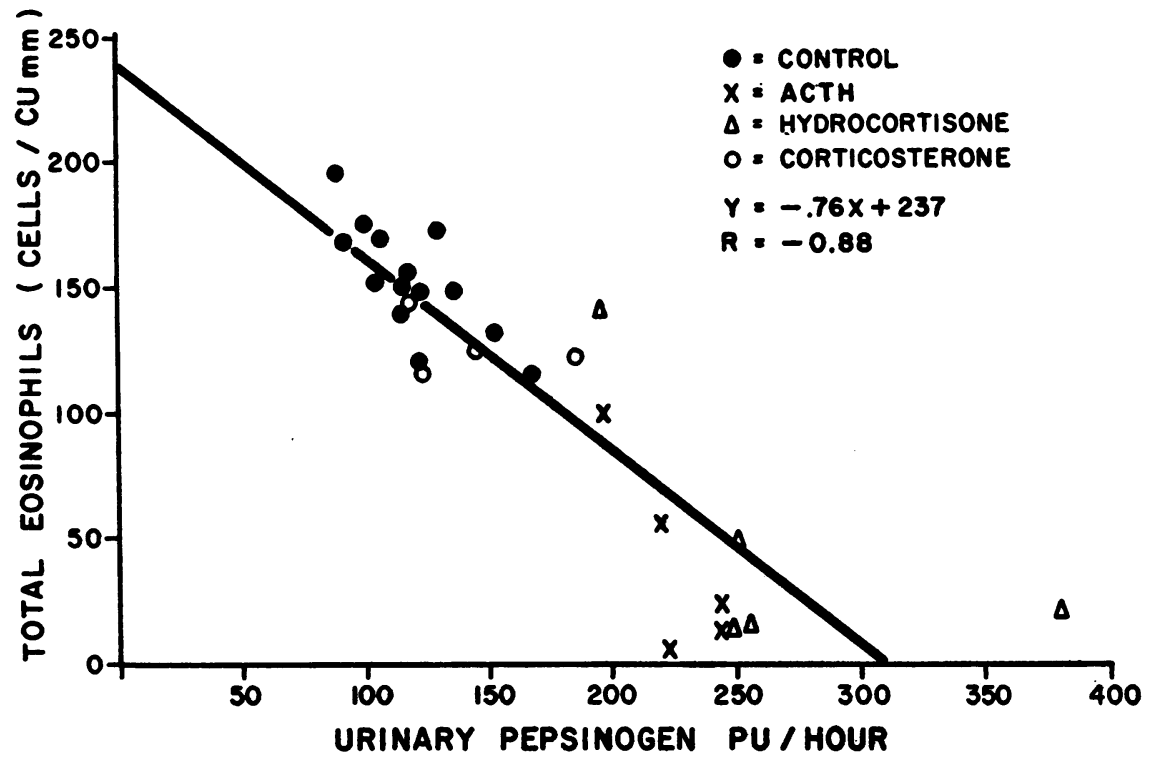

Fig. 3. Negative Corretation Betwefn the Mean Absolute Eosinophil Count and Smultaneous Urinary Pepsinogen Excretion

Each coordinate represents the mean values at successive periods in the respective experiments (see Tables I and VIII).

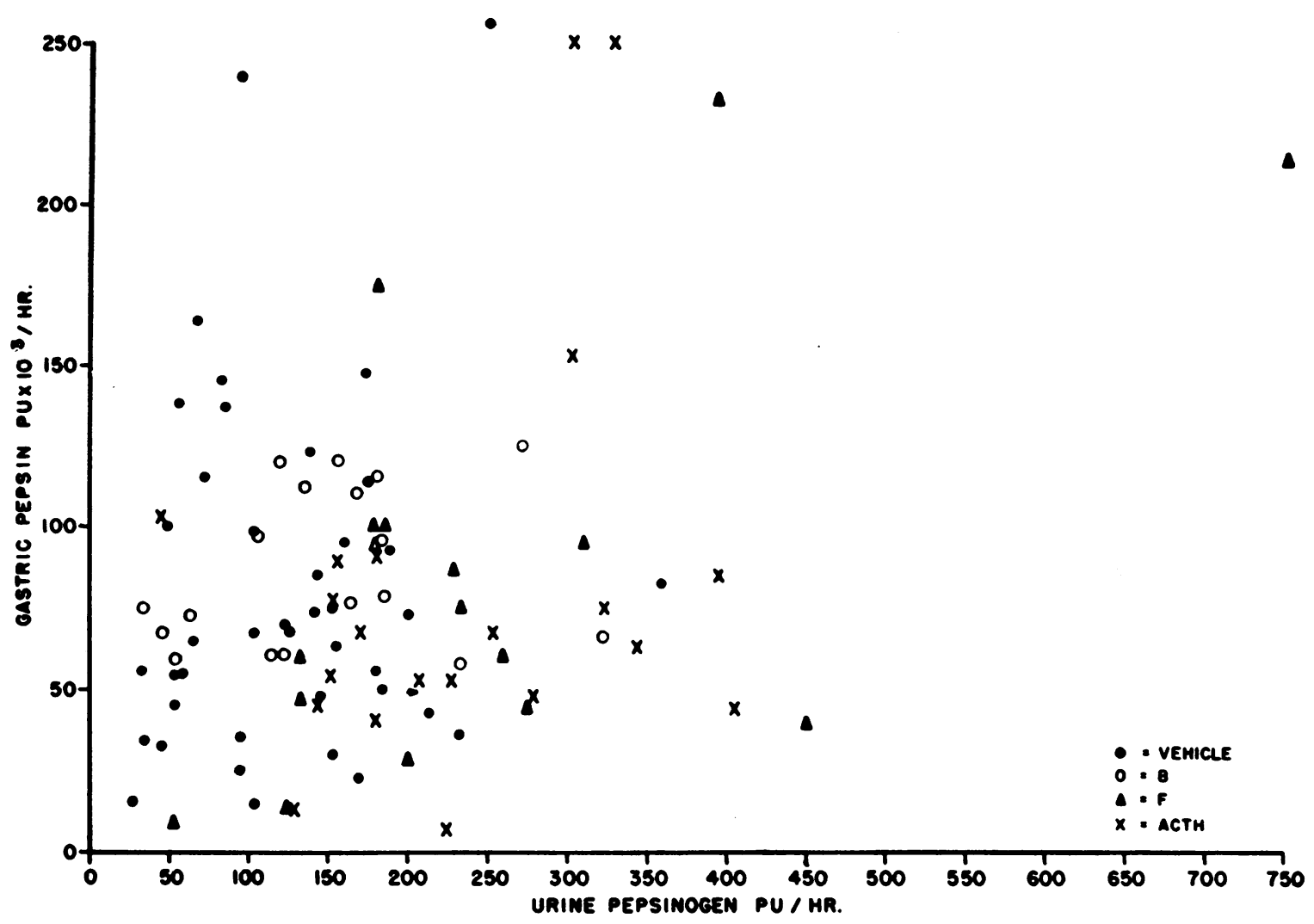

Fig. 4. Lack of Correlation Between the Output of Pepsin in the Gastric Juice and Simultangous Urinary Pepsinogen Excretion (See Text) 
control period of $830: 1$. Both ACTH and hydrocortisone produced a considerable drop in this ratio during the 8 hours of their infusion to a mean of $350: 1$, because of the increase in urinary pepsinogen out of proportion to any change in gastric pepsin secretion.

\section{DISCUSSION}

\section{Role of adrenal cortex in gastric secretion}

Rowntree and Snell (1) showed that hydrochloric acid secretion was depressed or absent in Addison's disease, and Escamilla and Lisser (2) that the same was true in Simmonds' disease. The mechanisms whereby the adrenocortical secretions maintain normal gastric secretion are not clear. The gastric hypofunction in Addison's disease may (4) or may not (3) be associated with gastric mucosal atrophy as judged by gastroscopy. Secretion in both cases was restored to normal by cortisone, with a return to normal of the mucosa in the former instance (4).

In animals there is evidence that both pituitary (9) and adrenal insufficiency (7-9) result in impairment of gastric secretion, and that the decrease in pepsin secretion is accompanied by involution of the chief cells with loss of ribonucleic acid (8, 9 ). Confirmation of this involution, noted histologically, was obtained by chemical analysis for pepsinogen which was decreased in the mucosa of the stomachs of adrenalectomized rats (11). Restoration of secretion with adrenal cortex extract (7) and of normal synthesis of pepsinogen by cortisone, corticosterone, hydrocortisone, and desoxycorticosterone, as well as by cortical extract (11), indicates the relatively nonspecific steroid requirements of the chief cells for normal function. It would thus appear that the adrenocortical secretions are necessary to maintain both structural and functional integrity of the gastric mucosa, probably acting in a permissive (6) or trophic role.

On the other hand, the evidence in support of a stimulant role for the adrenal cortex in gastric secretion is both inadequate and conflicting. Gray and his colleagues have claimed such a role for the adrenal both in acute (13) and in chronic experiments $(12,27,28)$. In the published evidence presented by these authors many of the values for gastric juice volume, acid and pepsin are within the limits of fluctuation in the basal state, and where significant increases were noted, these were usually in the second or third week of sustained high adrenocortical activity. The observations of these authors are supported by the finding in four dogs of a moderate, though inconsistent, increase in acid output while the animals were being given large doses of ACTH (14), and by unconvincing evidence of hypersecretion of acid in Cushing's syndrome (5). Moreover, much of the evidence for an increase in gastric secretion produced by ACTH and the adrenocortical steroids is indirectly derived from the increase in urinary pepsinogen excretion under the influence of these hormones $(27,28)$. As has been shown before $(15,29)$ and again in this paper, the rise in urinary pepsinogen is not a reflection of similar changes in gastric secretion. In contrast with the findings of Gray and his associates $(12,13,27,28)$, Kirsner and Ford (16) have recently reported that ACTH and cortisone administration over prolonged periods failed to increase gastric secretion in man, and Davenport and Chavré (30) failed to show any stimulant effects of cortisone on their in vitro preparations of mouse stomach. The present results have shown no evidence of any significant stimulation of the secretion of acid or pepsin by the infusions of ACTH, hydrocortisone or corticosterone. In order to place in their proper physiological perspective the effects of the hormone infusions on gastric secretion, the very pronounced effects of intravenous infusions of histamine have been described alongside those of the hormones. It is possible that the hormone infusions were too short to have caused any great changes in gastric secretion, though Villarreal, Ganong, and Gray (13) have described increases in gastric secretion within 4 to 6 hours of ACTH administration in dogs. Moreover, 5 subjects receiving ACTH-gel for 6 days (15) showed only small and inconsistent changes in gastric secretion, while 4 subjects receiving $150 \mathrm{mg}$. hydrocortisone orally daily for 20 to 30 days and two others, receiving $100 \mathrm{mg}$. cortisone acetate orally daily for $\mathbf{4 0}$ days showed no increase in acid or pepsin secretion in basal gastric secretion, determined twice weekly (18).

\section{The composition of gastric juice}

The principal change in the gastric juice observed in these experiments was a decrease in 
viscosity in subjects receiving ACTH or corticosterone. Hydrocortisone and prednisolone had no significant effect on viscosity. These results suggest that the effect of ACTH on viscosity was not mediated by hydrocortisone, and may have been mediated by corticosterone or by some other hormone or contaminant. A similar decrease in viscosity has been seen previously with more prolonged ACTH administration in man (15), and in dogs receiving ACTH (13). In adrenalectomized rats the viscosity of gastric juice is much increased (17), and hydrocortisone or cortisone produce a decrease of stainable mucus on the surface and in the pits of the gastric mucosa of rats (10). These results suggest an important but still unclear role of the adrenal cortex in the regulation of gastric mucus secretion.

With regard to the concentration of acid, there was no striking effect of ACTH, hydrocortisone or corticosterone. The one experiment in which aldosterone was given showed a fairly steep increase in $\mathrm{H}$ ion concentration. Of all the experiments, only the one with aldosterone had a clearcut stimulant effect on the concentration of pepsin in the gastric juice. While it would be unwise to draw sweeping conclusions from one experiment, the data are striking enough to deserve consideration. We have recently suggested (11) that sodium depletion in rats (in the face of adrenalectomy) results in gross depression of the synthesis of gastric pepsinogen. The apparently marked stimulation of gastric pepsin secretion by aldosterone, the most potent of the salt-retaining hormones, suggests that sodium may well play an important part in the secretion of pepsin as well as in its synthesis.

It is not surprising that many of the effects of ACTH, notably eosinopenia and urinary pepsinogen increase, were reproduced by hydrocortisone, in view of the release of a preponderance of this steroid from the human adrenal cortex stimulated by ACTH (25). On the other hand, not all of the effects of ACTH could be reproduced by hydrocortisone. The fall in gastric juice viscosity, for instance, was not observed in the hydrocortisone experiments, but did occur in the corticosterone experiments. This observation may have identified one physiological role for corticosterone in man.

\section{The control and significance of urinary pepsinogen excretion}

This study has confirmed that ACTH invariably increases the excretion of urinary pepsinogen and that such increases occur within a few hours of the start of the ACTH administration. It has also indicated that such increases did not reflect similar changes in gastric secretion. The evidence further shows that the changes observed with ACTH were the result of glucocorticoid activity, acting principally, if not wholly, on the kidney. The significant role of the glucocorticoids in the regulation of urinary pepsinogen excretion, found in these experiments, is supported by the positive correlations between urinary pepsinogen and urinary 17-hydroxycorticoids in Addison's disease, in Cushing's syndrome, and during ACTH stimulation (31).

The amount of pepsinogen excreted in the urine depends on at least three factors (29). Since the stomach is the source of urinary pepsinogen, the gastric peptic cell mass (21) in part determines whether there is none in the urine, as in pernicious anemia $(32,33)$ or an increased amount as in duodenal ulcer $(32,33)$, and especially so in longstanding duodenal ulcer (22), where the gastric peptic cell mass can reasonably be assumed to be increased.

The second factor involved is the secretion gradient of the peptic cells, that is, the proportion of the peptic cell pepsinogen which is secreted into the stomach, as compared with that passing into the blood. We have recently observed two cases $(15,34)$ in which the secretion gradient was reversed and a large proportion of the gastric cell pepsinogen passed into the blood and so into the urine, resulting in great increases in urinary pepsinogen, while the amount secreted into the stomach was strikingly reduced. The reasons for and mechanisms of this reversal are not known.

The third factor involved is the renal clearance of pepsinogen from the plasma. Under both the conditions mentioned above, the clearance of pepsinogen was normal (29) and the increases in urinary pepsinogen resulted directly from the elevated levels of plasma pepsinogen. On the other hand, the increases related to adrenal glucocorticoid activity occurred with unchanged plasma pepsinogen levels and little or no change in gastric 
pepsin secretion, and were due entirely to increases in pepsinogen clearance by the kidney.

A high level of urinary pepsinogen may therefore be found with a high, low, or normal amount of gastric pepsin secretion, depending on the particular set of circumstances under which it is measured. Conversely, there may be an increased amount of pepsin secreted into the stomach with a normal, or, less commonly, a decreased amount of pepsinogen excreted into the urine.

The lack of correlation between gastric pepsin and urinary pepsinogen found in this study may appear to differ strikingly from the positive correlation reported by Janowitz and Hollander (32). When the normal group included in their report is examined alone, however, there is little if any direct correlation between urinary and gastric pepsinogen. Their over-all correlation coefficient is weighted by the cases with pernicious anemia at one extreme and some of the cases with duodenal ulcers (increased peptic cell mass) at the other extreme.

\section{SUM MARY}

In 49 experiments on 16 normal subjects, the effects of 8-hour intravenous infusions of $\mathrm{ACTH}$, corticosterone, hydrocortisone, aldosterone and prednisolone on gastric secretion and on plasma and urine pepsinogen were compared with values found in the preceding 3-hour control period and with experiments in which no hormone was infused. The gastric effects of these hormone infusions were contrasted with 10 experiments in which histamine was infused for 4 hours.

No changes in concentration or output of acid or pepsin could be attributed unequivocally to the hormone infusions, except for a doubling of the acid and pepsin concentrations during the single infusion of aldosterone. The viscosity of the gastric juice was significantly reduced by ACTH and by corticosterone, but not by hydrocortisone, suggesting one possible role for the corticosterone which is secreted by the human adrenal.

ACTH invariably increased the output of urinary pepsinogen while the plasma pepsinogen levels remained unaltered, the increases being due entirely to an increased renal clearance of pepsinogen. These effects were reproduced by hydrocortisone and to a much smaller extent by corticosterone, while aldosterone had the opposite effect. An excellent negative correlation between the mean eosinophil count and the amount of pepsinogen in the urine indicated that the normal variations of pepsinogen in the urine were probably under control of the glucocorticoids. The reasons for the lack of correlation between gastric pepsin and urinary pepsinogen lie in the complex and ill-understood factors which govern the discharge of the enzyme from the gastric cells into the blood and in the secondary factors which determine the amount of the enzyme cleared from the blood by the kidney.

\section{ACKNOWLEDGMENTS}

We are grateful for the technical assistance of Mrs. Esther Dullaert and Mrs. Sararuth McCool. Dr. C. J. O'Donovan of the Upjohn Company of Kalamazoo, Michigan, kindly supplied us with generous amounts of corticosterone, prednisolone, and aldosterone.

\section{REFERENCES}

1. Rowntree, L. G., and Snell, A. M., A Clinical Study of Addison's Disease, 1st ed. Philadelphia, W. B. Saunders Co., 1931.

2. Escamilla, R. F., and Lisser, H., Simmonds' disease. A clinical study with a review of the literature. J. Clin. Endocrinol., 1942, 2, 65.

3. Stempien, S. J., and Dagradi, A., The histamine response of the gastric mucosa in a patient with adrenal insufficiency: Effect of cortisone administration. Gastroenterology, 1954, 27, 358.

4. Kyle, J., Gastric secretion in Simmonds' disease. Lancet, 1955, 2, 724.

5. Kyle, J., Logan, J. S., Neill, D. W., and Welbourn, R. B., Influence of the adrenal cortex on gastric secretion in man. Lancet, 1956, 1, 664.

6. Engel, F. L., Addison's disease and peptic ulcer. J. Clin. Endocrinol., 1955, 15, 1300.

7. Tuerkischer, E., and Wertheimer, E., Adrenalectomy and gastric secretion. J. Endocrinol., 1945, 4, 143.

8. Abrams, G. D., and Baker, B. L., The cytology and secretory activity of gastric zymogenic cells after ablation of ductless glands. Gastroenterology, 1954, 27, 462.

9. Baker, B. L., and Bridgman, R. M., The histology of the gastro-intestinal mucosa (rat) after adrenalectomy or administration of adrenocortical hormones. Am. J. Anat., 1954, 94, 363.

10. Baker, B. L., and Abrams, G. D., Effect of hypophysectomy on the cytology of the fundic glands of the stomach and on the secretion of pepsin. Am. J. Physiol., 1954, 177, 409. 
11. Hirschowitz, B. I., Streeten, D. H. P., and Pollard, $H$. M., Influence of adrenal cortex on gastric pepsinogen in the rat. Endocrinology, 1956, 59, 419.

12. Spiro, H. M., Reifenstein, R. W., and Gray, S. J., The effect of adrenocorticotropic hormone upon uropepsin excretion. J. Lab. \& Clin. Med., 1950, 35, 899.

13. Villarreal, R., Ganong, W., and Gray, S. J., Effect of adrenocorticotrophic hormone upon the gastric secretion of hydrochloric acid, pepsin and electrolytes in the dog. Am. J. Physiol., 1955, 183, 485.

14. Zubiran, J. M., Kark, A. E., and Dragstedt, L. R., The effect of ACTH on gastric secretion in experimental animals. Gastroenterology, 1952, 21, 276.

15. Hirschowitz, B. I., Streeten, D. H. P., Pollard, H. M., and Boldt, H. A., Jr., Role of gastric secretions in activation of peptic ulcers by corticotropin (ACTH). J. A. M. A., 1955, 158, 27.

16. Kirsner, J. B., and Ford, H., Gastric secretory stimulation: effects of phenylbutazone, histalog, ACTH, adrenal steroids and reserpine in man. J. Lab. \& Clin. Med., 1956, 48, 824.

17. Hirschowitz, B. I., Underhill, W. G., and Wiggins, H. S., Gastric secretion in the rat. I. Role of sodium and the adrenal cortex, In preparation.

18. Hirschowitz, B. I., Streeten, D. H. P., and Pollard, H. M., Failure to stimulate gastric secretion in man with prolonged treatment with glucocorticoids, In preparation.

19. Farmer, D. A., Burke, P. M., and Smithwick, R. H., Observations upon peptic activity of the gastric contents in normal individuals and in patients with peptic ulceration. Surg. Forum, 1953, 4, 316.

20. Hawk, P. B., Oser, B. L., and Summerson, W. H., Practical Physiological Chemistry, 12th ed. Philadelphia, The Blakiston Co., 1947.

21. Hirschowitz, B. I., Pepsinogen in the blood. J. Lab. \& Clin. Med., 1955, 46, 568.

22. Hirschowitz, B. I., Urinary excretion of pepsinogen in gastroduodenal ulceration. Lancet, 1953, 1, 66.
23. Reddy, W. J., Jenkins, D., and Thorn, G. W., Estimation of 17-hydroxycorticoids in urine. Metabolism, 1952, 1, 511.

24. Hirschowitz, B. I., Unpublished observations.

25. Hechter, O., and Pincus, G., Genesis of the adrenocortical secretion. Physiol. Rev., 1954, 34, 459.

26. Hirschowitz, B. I., Streeten, D. H. P., London, J. A., and Pollard, H. M., Effects of intravenous infusions of ACTH and adrenocortical secretions in normal man. II. Water balance, urine $\mathrm{pH}$ and electrolytes, In preparation.

27. Gray, S. J., Benson, J. A., Jr., Spiro, H. M., and Reifenstein, R. W., Effects of ACTH and cortisone upon the stomach: its significance in the normal and in peptic ulcer. Gastroenterology, 1951, 19, 658.

28. Gray, S. J., Benson, J. A., Jr., Reifenstein, R. W., and Spiro, H. M., Chronic stress and peptic ulcer. I. Effect of corticotropin (ACTH) and cortisone on gastric secretion. J. A. M. A., 1951, 147, 1529.

29. Hirschowitz, B. I., Significance of increased urinary pepsinogen (uropepsin) excretion in duodenal ulcer and during ACTH administration. J. Lab. \& Clin. Med., 1956, 48, 817.

30. Davenport, H. W., and Chavré, V. J., The lack of effect of the adrenal hormones upon gastric acid secretion. Endocrinology, 1950, 47, 193.

31. Krakauer, L. J., Ramsey, C. G., and Gray, S. J., The relationship of gastric activity and adrenocortical function: a correlative study. Clin. Research Proc., 1955, 3, 131.

32. Janowitz, H. D., and Hollander, F., Relation of uropepsinogen excretion to gastric pepsin secretion in man. J. Applied Physiol., 1951, 4, 53.

33. Mirsky, I. A., Block, S., Osher, S., and Broh-Kahn, R. H., Uropepsin excretion by man. I. The source properties and assay of uropepsin. J. Clin. Invest., 1948, 27, 818.

34. Hirschowitz, B. I., Streeten, D. H., London, J. A., and Pollard, H. M., A steroid-induced gastric ulcer. Lancet, 1956, 2, 1081. 